Biografistyka Pedagogiczna

Rok 2 (2017) nr 1

ISSN 2543-6112; e-ISSN 2543-7399

DOI: $10.36578 /$ BP.2017.02.20

Agnieszka Morska*

Karolina Szponar**

Tomasz Wach $^{\star \star \star}$

\title{
Relacyjność problemu nieregulaminowej absencji szkolnej - jako systemowe wyzwanie wychowawcze
}

\section{Relational Nature of the Issue of Impermissible School Absences as a Systemic Educational Challenge}

\begin{abstract}
The article analyses the issue of impermissible school absence on the basis of a systemic approach to the problem. It presents the social background of the decision process concerning truancy. The article shows the potential educational response aimed at solving the problem.
\end{abstract}

Keywords: School education, school absenteeism, school versus wagons

Nieregulaminowa absencja szkolna, inaczej określana jako wagarowanie, występuje we wszystkich placówkach bez względu na ich rodzaj. Oczywiście różne jest natężenie problemu oraz nasilenie poszczególnych czynników etiologicznych.

* Agnieszka Morska - studentka II roku sum pedagogiki na Katolickim Uniwersytecie Lubelskim Jana Pawła II w Lublinie.

** Karolina Szponar - studentka II roku sum pedagogiki na Katolickim Uniwersytecie Lubelskim Jana Pawła II w Lublinie.

*** Tomasz Wach (1961-2016) - dr hab. adiunkt w Instytucie Pedagogiki na Katolickim Uniwersytecie Lubelskim Jana Pawła II w Lublinie. 
Niniejsza wypowiedź skupia się na zagadnieniu wagarów w odniesieniu do gimnazjów, bo uznano, że okres nauki na tym poziomie szczególnie silnie łączy się z dojrzewaniem. Zatem poszukiwane są „pomysły” na siebie oraz - co w kontekście problemu tytułowego należy szczególnie podkreślić - testowany jest system reakcji społecznej na różne zachowania. Młodzież gimnazjalna poddaje weryfikacji oddziaływania dorosłych, będące elementem oferty socjalizacyjnej/wychowawczej. Rosnąca rola grupy rówieśniczej systemowo łączy się w nabywanym poczuciem samodzielności i dojrzałości. Naturalnie to subiektywne wrażenia gimnazjalistów, niemające czasem pokrycia w rzeczywistości, ale niezmiennie ważne dla procesów rozwojowych.

W swoistym obszarze „testowym”, dotyczącym poznawania reakcji otoczenia na przejawiane zachowania, młodzież lokuje także część, którą z punktu widzenia obiektywnej normy wychowawczej, należy nazwać ryzykowną. Wagary z pewnością zajmują tu istotne miejsce. Od razu należy podkreślić, że w obecnym artykule zostają one (wagary) połączone z innymi zachowaniami potencjalnie lub faktycznie mogącymi się wiązać z naruszeniami norm.

Mimo obecności pojęcia „wagary” także w języku potocznym, warto wskazać, że w literaturze specjalistycznej używa się ich do określenia zjawiska „samowolnego i obiektywnie nieuzasadnionego (pozbawionego rzeczywistych oraz istotnych powodów) opuszczania przez ucznia zajęć lekcyjnych, bez zgody oraz wiedzy rodziców i nauczycieli" ${ }^{\prime \prime}$. Etymologia tego określenia wiąże się z łacińskim vagari, co oznacza włóczenie się.

Definicja ta dotyczy każdego nieusprawiedliwionego przypadku absencji szkolnej, jednak należy tu nadmienić, iż po 1932 r. zaczęto dostrzegać sytuacje, gdy opuszczanie zajęć lekcyjnych było spowodowane swego rodzaju nerwicą związaną właśnie z wykonywaniem obowiązku szkolnego. Już kilka lat później tę formę absencji szkolnej nazywano „fobią szkolną”, jednak z czasem określenie to zostało zamienione na „odmowę chodzenia do szkoły”, co było dużo bardziej zrozumiałe i w lepszy sposób opisywało zachodzące zjawisko². W świetle tej uwagi wagary mogą nie być jedynie sposobem na ucieczkę od wykonywania

1 T. Pilch, Encyklopedia pedagogiczna XXI wieku, Warszawa 2008, s. 23.

2 D. Heyne, S. Rollings, Niechęć do szkoły. Jak pomóc dziecku, które opuszcza lekcje i wagaruje, Gdańsk 2004, s. 8. 
obowiązku szkolnego, a ich występowanie stanowić może dowód na pojawienie się zaburzeń psychicznych.

Pomiędzy wagarowaniem a odmową chodzenia do szkoły zachodzi kilka różnic, o których należy tu wspomnieć:

- o ile przy wagarach uczeń stara się zachować w tajemnicy przed rodzicami swoją absencję szkolną, o tyle w przypadku odmowy chodzenia do szkoły rodzic doskonale zdaje sobie sprawę z nieobecności dziecka na lekcjach;

- odmowa chodzenia do szkoły jest zjawiskiem stałym, dziecko permanentnie nie chce uczęszczać w zajęciach lekcyjnych, gdy z kolei wagary są w zamyśle zachowaniami występującymi sporadycznie i nie są spowodowane lękiem, a chęcią uniknięcia sprawdzianu, odpowiedzi klasowej lub przypodobaniu się grupie, która również bierze udział w wagarach;

- odmowa chodzenia do szkoły jest zaburzeniem emocjonalnym, wagary natomiast nim nie są i znacznie częściej wiążą się z innymi negatywnymi postawami np. paleniem papierosów, piciem alkoholu;

- uczeń wagarujący przejawia problemy wychowawczo-dydaktyczne, uczeń z odmową chodzenia do szkoły zwykle nie jest nimi obciążony.

Analiza specyfiki wagarów prowadzi do wyróżnienia ich typów, które można podzielić według następujących kryteriów:

- ze względu na częstotliwość występowania:

- okazjonalne - pojedyncze opuszczanie zajęć szkolnych, które występuje w długich odstępach czasowych;

- sporadyczne - wagarowanie częstsze niż okazjonalne, jednak nie systematyczne;

- systematyczne - częste opuszczanie zajęć lekcyjnych w krótkich odstępach czasowych;

- trwałe - absencja szkolna występująca nagminnie. Uczeń nie uczęszcza do szkoły przez wiele dni, tygodni a nawet miesięcy;

- ze względu na sposób realizacji:

- selektywne - opuszczanie poszczególnych zajęć lekcyjnych, najczęściej tych, które wymagają od niego zaprezentowania swojej wiedzy;

- całkowite - opuszczanie całego dnia w szkole;

- ze względu na podmiot wagarów:

- indywidualne - uczeń samotnie opuszcza miejsce nauki; 
- grupowe - jest to opuszczanie lekcji przez większą grupę osób ${ }^{3}$; wagary grupowe są zachowaniami konformistycznymi, spowodowane są chęcią dopasowania się do grupy.

Wagary są zjawiskiem cechującym się relacyjnością i dotykającym wszystkich środowisk, w których wychowuje się dziecko, m.in. szkoła, rodzina i oczywiście rówieśnicy. Mają one wiele przyczyn i skutków, które doprowadzają do zaburzeń w zachowaniu ucznia. Oczywiście wagary są także wynikiem wystąpienia pewnych trudności egzystencjalnych. Oczywiste jest więc, że rekomendowane może być podejście systemowe przy ich analizowaniu.

Przyczyny wagarów są różne i zależą od konkretnego ucznia bądź grupy uczniów. Dla jednych będzie to chęć uniknięcia sprawdzianu bądź odpowiedzi ustnych, dla innych - sposób wyrażenia swojej niechęci do konkretnego nauczyciela czy grupy nauczycieli, dla jeszcze innych - sposób zwrócenia na siebie uwagi rodziców lub wyrażenia swojego buntu osiągającego swoje apogeum w okresie dojrzewania, a jeszcze inni w ten sposób będą chcieli przypodobać się osobom, które również chodzą na wagary, a są swego rodzaju „idolami”.

Przedmiotem szczególnej uwagi wychowawczej powinny być sytuacje, gdy wagary układają się w ciągi, stają się częścią systemu zachowań ryzykownych, są wynikiem początkowo eksperymentu z normami społecznymi, ale po przekroczeniu pewnej skali - stają się problemem niejako samodzielnym. Zawsze jednak cyrkularnie wiążą się z pozostałymi, ryzykownymi przejawami zachowań. Wagary najczęściej wpisują się w ciąg zachowań ryzykownych, związanych z demoralizacją. Fakt ich wystąpienia jest przejawem niedostosowania społecznego dorastającej młodzieży, a często powtarzające się tego typu zachowania mogą stać się jednym z powodów do wszczęcia postępowania przez sąd i zastosowania środków wychowawczych na nieletniego i rodzinę.

Wagary doprowadzają do sytuacji, w której uczeń zaczyna nawiązywać kontakty ze środowiskami uznawanymi za patologiczne. Często zaczyna eksperymentować z używkami, począwszy od palenia papierosów i spożywania alkoholu, a skończywszy na zażywaniu środków psychoaktywnych. Często kolejnym krokiem jest nawiązywanie kontaktu z grupami przestępczymi, co skutkuje wchodzeniem w konflikt z prawem.

Takie sytuacje doprowadzają do występowania negatywnych emocji i zachowań przejawiających się w różnych formach. Z pewnością przerywają kontakt

3 T. Pilch. Encyklopedia pedagogiczna XXI wieku, s. 24. 
ucznia z pozytywnym systemem normotwórczym, uniemożliwiają też optymalna reakcję wychowawczą w sytuacji pojawienia się takiej konieczności.

Sytuacja nieregulaminowej nieobecności na zajęciach szkolnych jest operacjonalizacją pewnych decyzji, które uczeń podejmuje. Tym samym wcześniej musiało dojść do wystąpienia następujących, powiązanych ze sobą w system, okoliczności:

- zdobycia wiedzy, że wagary są możliwe, a także że w pewnych warunkach można je uzasadniać, kierując się kryterium korzyści dla siebie i otoczenia;

- wypracowania w sobie gotowości do analizowania sytuacji społecznych z elementem neutralizacji ich rzeczywistego znaczenia, czyli pojawienia się nastawienia do poszukiwania uzasadnień dla swoich postaw i zachowań w pewien sposób opozycyjnych do norm oficjalnych;

- pojawienia się „miejsca” w rekomendowanym przez otoczenie socjalizujące systemie normatywnym, pozwalającego lokować tam różne eksperymenty z normami.

Od razu należy wyjaśnić, że pewien zakres sprawdzania, jak mocno przestrzegane są normy, należy uznać za dopuszczalny. To m.in. w ten sposób młodzi ludzie budują sobie wizje świata i swojego w nim miejsca. Jednak konieczne jest podkreślenie, że zupełnie nie chodzi tu o zachowania polegające na narażaniu własnego czy cudzego życia. Tym samym „próba” wagarów staje się zrozumiała wychowawczo, jednak już jakieś intensyfikacje tych zachowań muszą budzić niepokój i wywoływać odpowiednie reakcje korekcyjne. Warto tu podkreślić, że problem wagarów jest - jak wspomniano - systemowy. Jeśli tak, to konieczne jest analizowanie go w kontekście innych zachowań ryzykownych. Dopiero na szerszym tle widać, jakie są usytuowania wagarów w całościowym nastawieniu młodego człowieka do otoczenia. Elementami takiej analizy są m.in.:

- ocena stanu wychowawczego człowieka przed pojawieniem się wagarów;

- dotarcie do określanych przez niego uzasadnień dla swoich zachowań, czyli przyjęcie informacji nt. problemów które za pomocą wagarów „rozwiązano”; - zbadanie występowania innych okoliczności obciążających w życiu człowieka. Wagary wchodzą w koincydencje z innymi okolicznościami, ale ponieważ są bardzo widoczne - mogą dominować w obrazie ucznia. Jednak warto dostrzec fakt, że są one z reguły wynikiem występowania jakichś niekorzystnych procesów. Po pewnym czasie mogą się stać problemem niejako samodzielnym, generującym kolejne trudności - ale niezmienne jest ich systemowe umocowanie w całości egzystencji ludzkiej. Młody człowiek analizuje rzeczywistość, w której 
funkcjonuje, podejmuje decyzje, że jakieś jego problemy mogą zostać rozwiązanie właśnie za pomocą omijania szkoły - to przecież czytelna wychowawczo informacje, że problem jest szeroki.

Dla wychowawców nieregulaminowa absencja uczniowska tworzy sytuację potrzeby „specjalnej”. Pojawia się uzasadnienie podjęcia interwencji, czyli działania nastawionego na eliminację niepożądanych zachowań i przywrócenie normy funkcjonowania w roli ucznia.

Tytułowa relacyjność omawianego problemu może zostać pokazana na przykładzie układu, cyrkularnie powiązanych okoliczności.

Rysunek 1. Cyrkularnie powiązane okoliczności wagarowania.

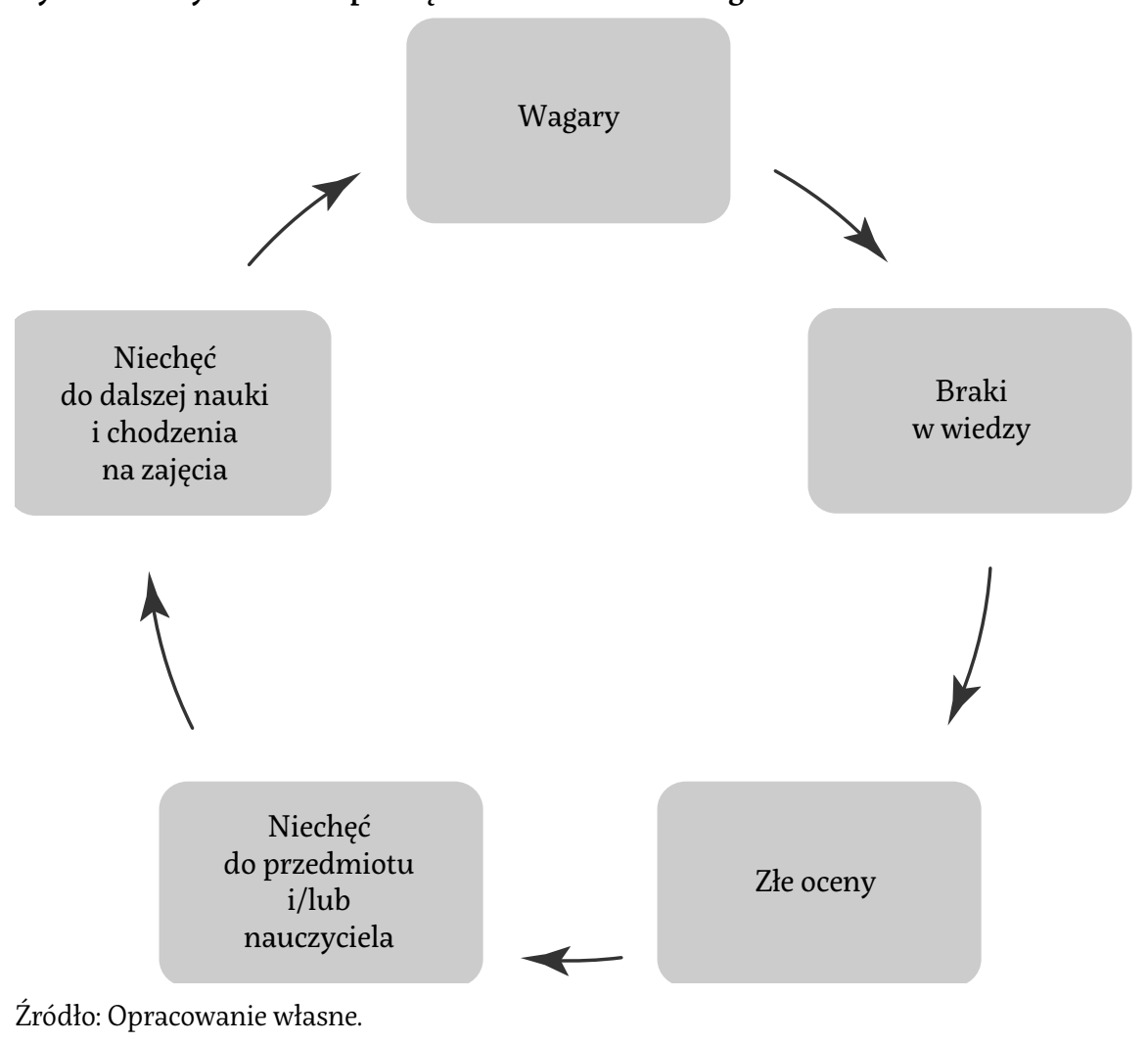

Gdy uczeń zaczyna wagarować i opuszcza pojedyncze godziny, często są to lekcje z tego samego przedmiotu, powoduje to brak wiedzy przekazywanej i wyjaśnionej na lekcji, na której uczeń jest nieobecny. Uczeń taki może nie 
poradzić sobie z przyswojeniem i zrozumieniem tej wiedzy samodzielnie, co z kolei prowadzi do otrzymywania przez niego negatywnej oceny z odpowiedzi ustnych lub sprawdzianów dotyczących tego zakresu materiału.

Należy zastanowić się, dlaczego uczeń boi się negatywnej oceny tak bardzo, że decyduje się na wagary.

W literaturze przedmiotu ${ }^{4}$ można znaleźć kilka powodów, dla których opuszczenie lekcji może być dla ucznia mniej kłopotliwe niż otrzymanie złej oceny, a są nimi:

- odbieranie jej jako porażki i negatywne jej oddziaływanie na samoocenę dziecka;

- poczucie braku szansy na odniesienie sukcesu edukacyjnego, w tym ukończenie dobrej szkoły i w konsekwencji znalezienie dobrej pracy;

- odczucie dyskomfortu i lęku przed kolejną porażką, pomimo włożonej pracy. Taki dyskomfort mogą odczuwać np. humaniści przed trudnym sprawdzianem lub poprawą tego sprawdzianu z matematyki czy chemii;

- poczucie bezradności i braku wiedzy dotyczącej sposobów poprawienia negatywnej oceny;

- obawa o karę otrzymaną w domu za niezaliczony sprawdzian. Obawa ta dotyczy to głównie kar cielesnych, które są także stosowane;

- zniechęcenie spowodowane porównywaniem do zdolniejszego rodzeństwa, a także kolegów czy koleżanek dziecka. Tego typu zachowania rodziców, a także wypowiadane przy tym komentarze często jeszcze bardziej obniżają samoocenę dziecka, a czasami nawet wzbudzają bunt, którego skutkiem jest jeszcze większe pogłębienie się problemów szkolnych dziecka;

- obawa przed niespełnieniem oczekiwań rodziców i nauczycieli;

- obawa, że zła ocena i trudność jej poprawy doprowadzi do powtarzania klasy;

- obawa przed wyśmianiem przez klasę. Dotyczy to zwłaszcza uczniów znajdujących się w nowej klasie;

- obawa przed utratą statusu "dobrego ucznia”.

Ostatni punkt wiąże się z obawą o brak zaspokojenia oczekiwań rodziców i nauczycieli oraz o wyśmianie przez klasę. Pozycja dobrego ucznia stanowi wtedy swego rodzaju tarczę zabezpieczającą ucznia.

4 A. Oleszkowicz, O. Bąk, A. Cieślik, Sposób na wagary. Jak radzić sobie z absencja uczniów?, Warszawa 2010, s. 47-48. 
Skutkiem otrzymania negatywnej oceny jest często niechęć do przedmiotu i/ lub nauczyciela na zasadzie: „ja tego nie rozumiem, a nauczyciel nie rozumie mnie”, a to z kolei prowadzi do kolejnego skutku, czyli niechęci do nauki (ponieważ skoro nauczyciel ma do mnie wciąż jakieś pretensje, to prawdopodobnie znowu wstawi mi złą ocenę, czyli nie ma sensu się uczyć, bo czy się nauczę, czy nie, będzie to samo).

Brak nauki i niechęć wobec przedmiotu lub nauczyciela przedmiotu powoduje ponowne opuszczanie lekcji i przybiera coraz groźniejszą formę, gdyż staje się ono swego rodzaju rozwiązaniem problemów szkolnych, choć w rzeczywistości jedynie je pogłębia, zamiast z kołem mamy więc do czynienia z narastającą spiralą, która tylko pogłębia problemy ucznia.

Oczywiście przedstawione tu przyczyny opuszczania lekcji nie są jedynymi. Jak już wcześniej zostało wspomniane, przyczyny te zależą od wielu czynników sytuacyjnych i cech osobowościowych ucznia.

Może się na przykład okazać, że uczeń nie wykazuje niechęci do nauczyciela lub przedmiotu, a także nie obawia się sprawdzianów, ale jego relacje interpersonalne w klasie są tak negatywne lub prawie nie istnieją, że uczeń, czując się odrzuconym, zaczyna opuszczać lekcje. Innym powodem absencji szkolnej może być niechęć do nowego środowiska lub nieumiejętność przystosowania się po zmianie szkoły.

Zarówno w odniesieniu do przedstawionego schematu, jak i do pozostałych możliwych powodów regulaminowej absencji szkolnej warto zastanowić się nad sposobem przerwania tego „zamkniętego koła”. W niniejszym tekście zostanie przedstawione kilka propozycji mogących wzbudzić pedagogów do podjęcia pracy nad zmniejszeniem lub całkowitym zniwelowaniem absencji uczniów na swoich lekcjach.

Sposoby postępowania nauczyciela zależą od tego czy były to wagary okazjonalne, czy też systematyczne lub trwałe, indywidualne czy też grupowe.

W przypadku wagarów okazjonalnych warto przeprowadzić z uczniem rozmowę, jednak nie może być ona jedynie udzielaniem reprymendy. Właściwie ten etap powinien występować na końcu, po poznaniu przyczyn skłaniających ucznia do podjęcia decyzji o ucieczce ze szkoły, a także po wzbudzeniu w uczniu refleksji dotyczącej jego zachowania. Nie powinien on jednak być rzucaniem rozkazów typu „Nigdy więcej nie chce słyszeć o tym że uciekasz ze szkoły”, a raczej „Mam nadzieję że zrozumiałeś/zrozumiałaś swój błąd i następnym razem zamiast uciekać od problemów spróbujesz się z nim zmierzyć". Nie powinna 
być to także rozmowa w pośpiechu z tzw. ręką na klamce. Należy umówić się z uczniem na konkretny dzień i godzinę, gdy nauczyciel będzie mógł poświęcić wystarczającą ilość czasu na zapoznanie się z sytuacją, która spowodowała wystąpienie wagarów u ucznia, co nie jest zadaniem prostym. Ważnym jest zadawanie uczniowi pytań nie tylko związanych z tym konkretnym wydarzeniem, ale także z całością jego życia, np. „Powiedz mi proszę, jak Ci idzie nauka? Nie potrzebujesz jakiejś pomocy? Czy jest w klasie ktoś komu szczególnie ufasz?"

Tego typu pytania pozwolą na poznanie sytuacji szkolnej ucznia, a być może odkryją nawet powód opuszczania przez niego lekcji w szkole. Jest to oczywiście trudne zadanie i czasami potrzebna jest pomoc pedagoga lub psychologa szkolnego. Jednak w sytuacji, gdy nauczyciel ma autorytet wśród uczniów, nie tylko ten formalny czyli narzucony i związany z wykonywaną funkcją, lecz ten nieformalny, który buduje sobie, pracując z uczniami, rozmowa z nimi nawet na tematy trudne jest dużo łatwiejsza.

Kolejnym sposobem, który może pomóc przy indywidualnych wagarach jest kontrakt, czyli umowa pomiędzy nauczycielem, a uczniem. Jest to sposób, który należy wykorzystać przy sporadycznych, bądź systematycznych wagarach. Podczas rozmowy obie strony ustalają zasady jego przestrzegania, nagrody i kary. W kontrakcie także powinien być ustalony termin naprawy zachowań negatywnych, jeżeli występują jeszcze jakieś inne oprócz wagarów, np. termin poprawienia ocen niedostatecznych. Kontrakt jest narzędziem pracy z nieletnimi, używanym często m.in. przez kuratorów sądowych. Nie należy się jednak bać wykorzystywać go również w pracy w szkole. Podczas rozmowy warto również przedstawić uczniowi skutki jego dalszych wagarów, w tym także skutki prawne takie jak nieotrzymanie promocji do następnej klasy czy usunięcie ze szkoły.

W przypadkach trudniejszych i przy wagarach systematycznych bądź trwałych warto zastanowić się nad skierowaniem dziecka do poradni psychologicznej czy psychologiczno-pedagogicznej w celu głębszej diagnozy. To do nauczyciela należy przeprowadzenie diagnozy wstępnej i przekazanie swoich spostrzeżeń rodzicom dziecka, zachęcenie ich do konsultacji psychologicznej, a jeżeli zajdzie taka możliwość współpraca z psychologiem, chociażby poprzez przekazywanie mu bieżących informacji na temat ucznia, czy pomoc w realizacji programu terapeutycznego ${ }^{5}$.

5 Tamże, s. 110. 
Jeżeli jednak wychowawca ma w swojej klasie przypadki grupowej absencji szkolnej, w pierwszym momencie należy sprawdzić, jak duża grupa opuściła lekcje. Jeżeli była to cała klasa, z wyjątkiem jednej lub kilku osób, lub była to mniejsza grupa zawsze tych samych osób, to absencja może mieć podłoże towarzyskie, mianowicie osoby, które wciąż uciekają z lekcji, lub te, które nie wzięły udziału w wagarach z całą klasą, mogą czuć się odtrącone przez resztę grupy.

$\mathrm{W}$ takiej sytuacji wskazane byłoby przeprowadzenie socjometrii, w postaci „plebiscytu życzliwości". Socjometria jest to „dział socjologii obejmujący teorię, metody i techniki badawcze pomiaru zachowania się ludzi, głównie zjawisk zachodzących w małych grupach społecznych"6. Oznacza to, że dzięki badaniom socjometrycznym możemy odkryć sympatie i antypatie występujące w grupie.

Badanie socjometryczne polega na zadaniu wszystkim badanym osobom pytań, podczas których badany dokonuje wyboru i określa swoje odczucia wobec pozostałych członków grupy. Przykładowe pytania socjometryczne mogą brzmieć: kogo wybrałbyś na przewodniczącego klasy? Z kim nie chciałbyś być w pokoju podczas wycieczki szkolnej? Komu z klasy powierzyłbyś swoją największą tajemnicę?

Uczeń udziela odpowiedzi na karcie, na której widnieją imiona i nazwiska wszystkich osób z klasy. Przy każdym imieniu i nazwisku wstawia jeden z symboli określających jego odczucia wobec konkretnej osoby. Odpowiedzi mogą przyjmować różne skale, np. liczbową - od 1 do 5 , lub być w postaci tzw. buziek od uśmiechniętej przez obojętną do smutnej. Ważne jest, aby skala odpowiedzi była dobrze zrozumiana przez ucznia w chwili rozpoczęcia badania. Przeprowadzenie takich badań pomaga w sprecyzowaniu wniosków dotyczących integracji uczniów w klasie.

Ponadto wychowawca, który w swojej klasie spotyka się z systematycznymi wagarami grupowymi, powinien przeprowadzić najlepiej serię lekcji wychowawczych, dotyczących tego problemu. Może poprosić o pomoc w przeprowadzeniu takich zajęć osoby posiadające większy autorytet, np. kolega nauczyciel, a w sytuacjach większych nasileń problemu wręcz musi zaangażować kogoś zawodowo zajmującego się tego typu kwestiami. Niezmiennie warto pamiętać, że niepokojące są wagary wchodzące w korelacje z innymi zachowaniami ryzy-

6 E. Sobol, Słownik wyrazów obcych, Warszawa 200o, s. 1023. 
kownymi. Konieczne może okazać się nawet powiadomienie sądu rodzinnego, wszak wagary są wymieniane w katalogu zachowań świadczących o demoralizacji i system szkolny ma obowiązek informować o przypadkach nasileń i postaci zjawiska, które mogą zakłócić proces wychowania.

Bez względu na typ wagarów każde działanie kuratora sądowego powinno być poprzedzone rozmową z rodzicami dzieci wagarujących. Także od ich postawy zależy skuteczność działań wychowawcy.

Biorąc pod uwagę wszystko to, co zostało napisane, można stwierdzić, że w sytuacji nieregulaminowej absencji ucznia w szkole wychowawca, gdy spotyka się z problemem nieregulaminowej absencji szkolnej w swojej klasie, powinien postępować według następujących kroków.

Rysunek 2. Etapy postępowania w celu przeciwdziałania absencji ucznia w szkole.

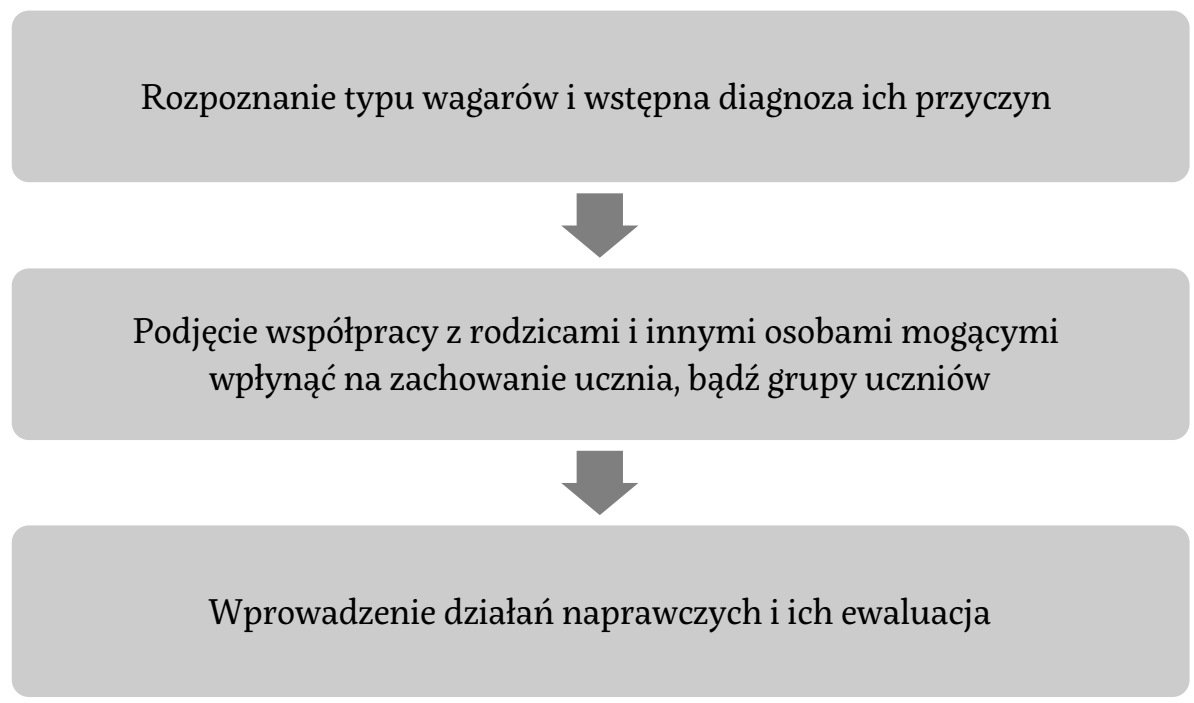

Źródło: Opracowanie własne.

Podsumowując, należy stwierdzić, iż wagary są tematem bardzo szerokim i pełne ich omówienie nie jest zadaniem łatwym. Przedstawiony tekst w sposób skrócony i jak najbardziej czytelny stara się omówić ten temat, zwracając uwagę na przyczyny występowania nieregulaminowej absencji szkolnej, określa jej różne rodzaje, sposoby reagowania nauczyciela/wychowawcy oraz przedstawia sposób diagnozy integracji grupowej, jaką jest socjometria. 
Wagary bez wątpienia są problemem i to problemem narastającym, ale przy podjęciu starań i odpowiednim dobraniu tych działań do charakteru problemu jest możliwe jego zmniejszenie, a nawet zniwelowanie. Nie jest to zadanie proste, jednak kompetencje i kwalifikacje wychowawców pozwalają im na zaproponowanie i skuteczne wprowadzanie takich działań, które pozwolą na poradzenie sobie z zaistniałą sytuacją.

Bez względu na podjęte działania należy pamiętać, że wagary są zjawiskiem relacyjnym, a ich występowanie u każdego z uczniów ma inne przyczyny i prowadzi do innych skutków.

Streszczenie: $\mathrm{W}$ artykule autorzy analizują kwestię niedopuszczalnej nieobecności w szkole na podstawie podejścia systemowego do problemu. Przedstawiają społeczne tło procesu decyzyjnego dotyczącego awanturnictwa. Przedstawiono tu potencjalną odpowiedź edukacyjną mającą na celu rozwiązanie problemu.

Słowa kluczowe: edukacja szkolna, wagary, szkoła wobec wagarów

\section{Bibliografia}

Heyne D., Rollings S., Niechęć do szkoły. Jak pomóc dziecku, które opuszcza lekcje i wagaruje, Gdańsk 2004.

Oleszkowicz A., Bąk O., Cieślik A., Sposób na wagary. Jak radzić sobie z absencja uczniów?, Warszawa 2010.

Pilch T., Encyklopedia pedagogiczna XXI wieku, Warszawa 2008.

Sobol E., Słownik wyrazów obcych, Warszawa 2000. 